\title{
Incidence of lumpy skin disease among Egyptian cattle in Giza Governorate, Egypt
}

\author{
Fayez Awadalla Salib* and Ahmed Hassan Osman \\ Department of Medicine and Infectious Diseases, \\ Faculty of Veterinary Medicine, Cairo University, Egypt. \\ * Corresponding author
}

\begin{abstract}
The present study was conducted on 500 cattle of different breed in Giza governorate. Their age ranged from 1-7 years of different sexes. All suspected animals were clinically examined. The recoded lesions including the complicated cases in different age and sexes were described. The infected animals were classified according to the severity of clinical status into mild and severe forms. The severe form was recorded in all ages and both sexes in the frezian cattle and some of the native ones while the mild form was recorded in native cattle. The morbidity, mortality and case fatality rates of LSD among examined Egyptian cattle were 100\%, 1.8\%, and 1.8\% respectively. Grossly lumpy skin lesions appeared as nodules 1 to $7 \mathrm{~cm}$ in diameter and occurred anywhere on the animal body. The hair stands erected over early skin lesions. The nodules involved the epidermis, dermis, and subcutaneous tissue and may even spread to the musculature. Histopathological examinations of lumpy skin disease revealed ballooning degeneration of stratum spinosum with microvesicles formation. Eosinophilic intracytoplasmic inclusion bodies specific for LSD were detected by electron microscopy. The main target of treatment trials was to save the animal life and to prevent LSD complications.
\end{abstract}

Keywords: Lumpy skin, Epidemiology, pathology, Electron microscopy, Treatment.

\section{I ntroduction}

Lumpy skin disease (LSD, Pseudo-urticaria, Neethling virus disease, exanthema nodularis bovis and knopvelsiekte) was first described in Northern Rhodesia in 1929 by Morris (1930). Since then, the disease has spread over most of Africa in a series of epizootics as previously recorded by Davies (1991) and House (1990). The most recently affected countries include Kuwait in 1986-88 as mentioned by Anonymous (1988) and Israel in 1989 as previously recorded by Shimshony (1989). LSD was recorded in Egypt in 1988 where it was diagnosed clinically in Suez Canal governorate then spread to the surrounding governorates in the summer of the same year and apparently over-wintered with little or no manifestations as reported by Salem (1989). LSD appeared in Egypt after importation of cattle from African countries. The diseases reappeared in Egypt at the summer of 1989 and, in a period of five to six months, it had been spread to 22 out of 26 Egyptian governorates. Morbidity rate was low, being $2 \%$ of whole Egyptian cattle population and approximately 1449 animals died (Davies).

In summer of 2006, outbreak of LSD was recorded in several Egyptian governorates. All age groups and both sex of Egyptian cattle were infected with severe and serious complications. Clinical signs, epidemiological characters, histopathological findings and electron microscopical features of LSD in this outbreak were recorded in this study. Treatment trials using different drugs were tried.

\section{Material and methods}

I- Animals population: The present study was conducted on 500 cattle in Giza governorate farms, slaughter houses and some of them were admitted to the clinic in Faculty of Veterinary Medicine Cairo University, these animals were examined during the outbreak of lumpy skin disease in April, May, June and July 2006. Their age ranged from 1-7 years and of different sexes. Most of the examined cattle were infected with foot and mouth diseaese preceding LSD infection.

II-(1)-Clinical examinations, observations of lesions and complications in diseased animals: All suspected animals were clinically examined. The animal examination was concentrated on physical statutes, temperature, superficial lymph node and skin lesions according to (Rodostits, et al 1995). Gross lesions and complicated cases of different age and sexes were recorded.

II-(2)-Epidemiological features of lumpy skin 
Table (1): Epidemiological data of Lumpy Skin Disease.

\begin{tabular}{|c|c|c|c|c|c|c|c|}
\hline \multirow[t]{2}{*}{ Age of examined animals } & \multicolumn{3}{|c|}{ Native } & & \multicolumn{3}{|c|}{ Frezian } \\
\hline & Male & Female & Total & & Male & Female & Total \\
\hline $\begin{array}{l}\text { Up to } 2 \text { years } \\
2.5 \text { years-3years } \\
3.5 \text { years- } 4 \text { years } \\
4.5 \text { years or more } \\
\text { Total }\end{array}$ & $\begin{array}{l}20 \\
10 \\
80 \\
30 \\
140\end{array}$ & $\begin{array}{c}30 \\
40 \\
120 \\
120 \\
310\end{array}$ & $\begin{array}{l}50 \\
50 \\
200 \\
150 \\
450\end{array}$ & & $\begin{array}{c}3 \\
5 \\
10 \\
2 \\
20\end{array}$ & $\begin{array}{c}2 \\
15 \\
5 \\
8 \\
30\end{array}$ & $\begin{array}{c}5 \\
20 \\
15 \\
10 \\
50\end{array}$ \\
\hline \multicolumn{8}{|c|}{ B- Morbidity, Mortality and Case fatality in different breeds, sexes and ages. } \\
\hline Breed, Sex, Age & $\begin{array}{l}\text { Number of } \\
\text { the infected }\end{array}$ & & & $\begin{array}{c}\text { Morbidity } \\
(\%)\end{array}$ & & $\begin{array}{c}\text { Mortality } \\
(\%)\end{array}$ & $\begin{array}{c}\text { Case Fatality } \\
(\%)\end{array}$ \\
\hline $\begin{array}{l}\text { Native cattle } \\
\text { Frezian cattle } \\
\text { Male cattle } \\
\text { Female cattle } \\
\text { Up to } 2 \text { years } \\
2.5 \text { years-3years } \\
3.5 \text { years- } 4 \text { years } \\
4.5 \text { years or more } \\
\text { Total }\end{array}$ & $\begin{array}{c}450 \\
50 \\
160 \\
340 \\
55 \\
70 \\
215 \\
160 \\
500\end{array}$ & & & $\begin{array}{l}100 \\
100 \\
100 \\
100 \\
100 \\
100 \\
100 \\
100 \\
100\end{array}$ & & $\begin{array}{c}1.4 \\
0.004 \\
1 \\
0.8 \\
1.2 \\
0 \\
0 \\
0.6 \\
1.8\end{array}$ & $\begin{array}{c}1.4 \\
0.004 \\
1 \\
0.8 \\
1.2 \\
0 \\
0 \\
0.6 \\
1.8\end{array}$ \\
\hline
\end{tabular}

T-test (P-value) for LSD infected cattle was: for native and frezian cattle $=0.037$ (statistical significant difference), for male and female cattle $=0.045$ (statistical significant difference) and for up to 2 years and 4.5 years or more $=0.07$ (no statistical significant difference)

disease outbreak: Effect of breed, sex and age of infected animals were studied in all infected animal. Morbidity, mortality and case fatality of the disease were also calculated among examined animals. Statistical differences between cattle groups were done by using T-test according to Wayne et al (1987).

I I-(3)-Pathological examination: Gross, histopathological and semithin sections examinations of skin lesions were done. Histopathological sections were carried out by fixing of skin biopsy of living animals and skin samples of died animals in $10 \%$ neutral buffered formalin solution. The fixed specimens were trimmed, washed and dehydrated in ascending grades of alcohol, cleaned in xylene, embedded in paraffin then sectioned (4-6 micron) and stained with hematoxyline and eosin according to Bancroft et. al., (1996). Semithin sections were carried out by fixing in $5 \%$ glutaraldehyde then possessed for sectioning by ultra microtome in thickness of 1 micron. The sections were stained by Toluidine blue according to Bancroft et. al.,(1996). The samples were prepared in electron microscope unite of VACSERA company.

I I-(4)- Treatments trials for LSD infected cattle and its complications: The following drugs were used to treat LSD infected cattle and to ease its complications and secondary bacterial infections. These medicines were applied as a symptomatic treatment and our main target was to save the animal life and to prevent LSD complications. Terramycin ${ }^{\circledR}$ long acting (oxytetracycline) was injected intramuscularly in a dose rate of $1 \mathrm{ml} / 10 \mathrm{~kg}$ body weight, $10 \mathrm{ml}$ of levamizole ${ }^{\circledR}$ (levamizole) per animal was also injected subcutaneously, $20 \mathrm{ml}$ of Novacid ${ }^{\circledR}$ (metamizol) per animal was injected intravenously twice daily and repeated until fever subsided. $12 \mathrm{ml}$ of Declofenile ${ }^{\circledR}$ (declofenic sodium) per animal was injected intramuscularly once daily and repeated until fever subsided. The complications of LSD were treated and result of treatment was recorded in table (3).

\section{Results}

In this study, lumpy skin disease virus causes inapparent to severe disease in cattle. All ages of cattle were affected, but young calves were more severely affected. The severity of the disease as measured by number of lumps and occurrence of complications, depends on the dose of the inoculum as well as the susceptibility of the host and the density of insect population. Results of different investigations are illustrated in the following:

\section{1- Results of clinical examination:}

The infected animals were classified according to the severity of clinical status into:

(I) Mild form: It was only observed in Egyptian native cattle which, appeared as one or two lumps. Some cases showed detached lumps leaving ulcer. The 
Incidence of lumpy skin disease among Egyptian cattle in Giza Governorate, Egypt

Table-2.: Incidence of complications of LSD and its differentiation from urticaria.

\begin{tabular}{|c|c|c|}
\hline \multicolumn{3}{|l|}{ A- Incidence of complications of LSD } \\
\hline The complications & \multicolumn{2}{|c|}{ Number and percentage of animals suffered from LSD complications } \\
\hline $\begin{array}{l}\text { Corneal opacity (Keratitis) } \\
\text { Recumbency } \\
\text { Mastitis } \\
\text { Cellulitis and phligmone } \\
\text { Myiasis } \\
\text { Abortion } \\
\text { Dysentry } \\
\text { Lameness } \\
\text { Pneumonia }\end{array}$ & \multicolumn{2}{|c|}{$\begin{array}{l}5(1 \%) \\
4(0.8 \%) \\
10(2 \%) \\
100(20 \%) \\
20(4 \%) \\
2(0.4 \%) \\
6(1.2 \%) \text { (in calves) } \\
30(6 \%) \\
5(1 \%)\end{array}$} \\
\hline \multicolumn{3}{|c|}{ B- Differentiation of LSD (Pseudo-Urticaria) from Urticaria among examined animals. } \\
\hline Items & Urticaria & LSD(Pseudo-Urticaria) \\
\hline $\begin{array}{l}\text { Lesions } \\
\text { Seasonal incidence Summer } \\
\text { Course of the disease } \\
\text { Healing or recovery } \\
\text { Diagnostic therapy } \\
\text { (Anti-histaminics and calcium injection) }\end{array}$ & $\begin{array}{l}\text { Wheals } \\
\text { Summer } \\
\text { (It was caused by insect bite) } \\
\text { Animal recover within two hours } \\
\text { Does not leave ulcer or scar } \\
\text { Is effective }\end{array}$ & $\begin{array}{l}\text { Lumps and nodules } \\
\text { Summer } \\
\text { (It was transmitted by insect) } \\
\text { Animal recover within } 2-4 \text { months } \\
\text { Leave ulcer and scar } \\
\text { Is not effective }\end{array}$ \\
\hline
\end{tabular}

hair stands erected over early skin lesions. Generally within 2 days after onset of the fever, swellings or nodules 1 to $5 \mathrm{~cm}$ in diameter appears in the skin and virus localization was occurred. Depression, anorexia, excessive salivation, oculonasal discharge, agalactia, and emaciation were also noticed. Nodular lesions were seen on the animal body especially in the skin of the muzzle, nares, back, legs, scrotum, perineum, eyelids, lower ear, nasal and oral mucosa, and tail. The nodules were painful and hyperemic.

(II) Severe form: The severe form was recorded in all ages and both sex in Frezian cattle and some of the native cattle which firstly suffered from fever $\left(40.5 \mathrm{C}^{\circ}\right.$ $40.5 \mathrm{C}^{\circ}$ ) that persisted for 7-12 days. Intradermal lumps of variable numbers (up to hundreds) were detected (Fig-1).. Variable sized lumps covered whole animal body. Subcutaneous and intra-muscular nodules were also observed. Keratitis (unilateral or bilateral) was also seen. Swelling of brisket, umbilicus, face and one or four legs was observed. This swelling ruptured oozing pus. Big ulcer behind knee joint was common. Recumbency was rare, usually in weak and old animal and a low incidence of abortion was also recorded. Moreover, Frezian cattle showed high incidence of scab formation after rupturing of nodules. Secondary bacterial infection retarded healing and recovery. Superficial lymph nodes were swollen, nasal discharge and respiratory manifestations were also noticed.

Ulcers arised from detached skin nodules with eroded blood vessels and in nerves, tendons, joints and testis were present. Healing of skin ulcers by scar tissue were observed after 4 months .

Drop in milk production, lumps on teats and udder was observed. Red (bloody) colostrum was observed in two, 7 months pregnant cows at day of delivery which lasted for 3 days. Newly born calves from LSD infected cows were weak and died soon after birth. Cachexia and emaciation of infected animals were prominent and lasted for 2 months. Recovered animals need long time (2-4 months) to get back its body condition. Incidence of different complications were illustrated in table(2-A). Some of the examined animals were showing signs of urticaria ( 5 cattle) that might be confused with LSD infected animals. These animals proved to be free from LSD infection and were differentiated as illustrated in table(2-B).

\section{2- Results of epidemiological studies:}

Effect of breed, sex and age of infected animals were studied. Detected difference between these variants were statistically evaluated according to Wayne et al (1987). The results are illustrated in tables (1).

\section{3- Results of pathological findings:}

3-A- Gross pathological changes: Grossly lumpy skin lesions appeared as nodules 1 to $7 \mathrm{~cm}$ in diameter and occurred anywhere on the animal body. The hair were standing erected over early skin lesions. The nodules involved the epidermis, dermis, and subcutaneous tissue and may even spread to the musculature. As the disease progresses, the nodules became necrotic, and eventually a deep scab was formed; this lesion is called a sitfast. 
Table-3.: Treatment of complications

\begin{tabular}{|c|c|c|}
\hline Symptoms & Drugs & Response \\
\hline Recumbency & $\begin{array}{l}\text { Tonics solutions }(\mathrm{Cal}-\mathrm{d}-\mathrm{mag} \AA \text {, } \\
\text { Cafosal®, AD3 } \mathrm{E} \AA \text { and dextrose } \\
5 \% ®) \text { as intravenous infusion }\end{array}$ & Bad response in old pregnant cows \\
\hline Mastitis & Mastalone $\AA$ (udder infusion) & Recovery was in 5 days \\
\hline Cellulitis and pheligmone & $\begin{array}{l}\text { Streptopencid } \AA \text { + Declofenile } \AA \\
\text { (preganant) or Dexamethazone } \AA \\
\text { (non preganant) }\end{array}$ & $\begin{array}{l}\text { Recovery was in } 5 \text { days but few case required surgical } \\
\text { evacuation of pus }\end{array}$ \\
\hline Myiasis & $\begin{array}{l}\text { Washing by warm water, } \\
\text { removing larvae and dressing } \\
\text { by Betadine } \AA\end{array}$ & Recovery was with in two weeks \\
\hline Abortion & $\begin{array}{l}\text { Aborted cow was injected by } \\
\text { Terramycin- long acting } \AA \text { as a } \\
\text { prophylactic dose }\end{array}$ & ------ \\
\hline Pneumonia & $\begin{array}{l}\text { Streptopencid } \AA \text { + Declofenile } \AA \\
\text { (preganant) or Dexamethazone } \AA \\
\text { (non preganant) + Hisacure } \AA\end{array}$ & Recovery was in 5 days \\
\hline
\end{tabular}

Note: Oxytetracycline Dexamethasone suspension (Mastalone $\left.{ }^{\circledR}\right)$, Dexamethasone sodium phosphate (Dexamethasone ${ }^{\circledR}$ ), (diphinhydramine hydrochloride) Histacure ${ }^{\circledR}$, Penicillin Streptomycin (Streptopenicid $₫$ ), Neomycin, Sulphaguanidine, Vitamin$A$, Bismuth Subnitrate, pectin and kaolin (New-deaclin $\left.{ }^{\circledR}\right)$, vitamins $A, D_{3}$, and $E\left(A D_{3} E \circledast\right)$, 1-(n-Butylamino) 1 -methylethyl phosphonous acid and Vitamin $B_{12}$ (Cafosal $\left.{ }^{\circledR}\right)$, calcium - magnesium and dextrose solution (Cal-D-mag $\left.{ }^{\circledR}\right)$ and bovidone iodine anti-septic solution (Betadine ${ }^{\circledR}$ )

3-B-Histopathological findings: Histopathological examinations of lumpy skin disease revealed ballooning degeneration of stratum spinosum with microvesicles formation. Eosinophilic intracytoplasmic inclusion bodies were also noticed (Fig-2). The vesicles were filled with serofibrinous exudates. The epidermal layer showed focal areas of liqufactive necrosis and infiltrated with large number of neutrophils, lymphocytes and macrophages. The dermal layer showed necrosis with massive infiltration of inflammatory cells mainly neutrophils. Vasculitis of dermal blood vessels which appeared as thickening of it's wall and surrounded by large number of inflammatory cells were seen. The lesions was extended to subcutaneous tissue and associated with Zenker's necrosis of muscular layer. Semithin section of dermal layer revealed vasculitis with projection of endothelial lining to the lumen of the vessels. Focal aggregation of inflammatory cells was seen around the blood vessels. The dermal stoma was infiltrated with mixture of red blood cells, lymphocytes, neutrophils and macrophages containing intracytoplasmic inclusion bodies specific to LSD virus infection.

4-Results of treatment trials: These were illustrated in table(3).

\section{Discussion}

Lumpy skin disease (LSD) is an acute to chronic viral disease of cattle characterized by skin nodules that may have inverted conical necrosis (sitfast) with lymphadenitis accompanied by a persistent fever. The LSDV is very closely related serologically to the virus of sheep and goat pox (SGP) from which it cannot be distinguished by routine virus neutralization or other serological tests, Burdin (1959) and Tuppurainen et al (2005). The LSDV is very resistant to physical and chemical agents. The virus persists in necrotic skin for at least 33 days and remains viable in lesions in airdried hides for at least 18 days at ambient temperature Shimshony, (1989).

LSD outbreak was recorded in Egypt after importation of cattle from African countries in 2006. Two clinical forms of LSD were recorded among Egyptian cattle in this study mild and severe. The severity of the disease depends on the dose of the inoculum as well as the susceptibility of the host and the route of exposure as reported by Davies (1981). In this study, mild form of LSD was only observed in native cattle which was characterized clinically by few number of nodules while the severe form was present in frezian cattle and some the natives.

It appeared that our native breeds examined in this study have less susceptibility to the disease than frezian cattle. This come in agreement with the findings of Capstick et al(1959). Animals suffered mild form, 


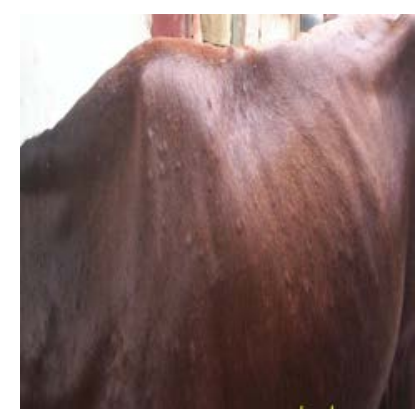

Figure-1: Skin nodules in Egyptian cow (Early stage of LSD)

may have stronger immune response which concentrated the virus lesions in one or two skin. These findings were coincided with Anonymous, (1988). Morbidity rate of LSD in examined cattle reach to $(100 \%)$ as presented in table (2), which is supported by Davies (1981) who mentioned that LSD morbidity rates may reach $80-90 \%$ under certain circumstances.

Although LSD virus is genetically and antigenically related to sheep pox virus (Bhanuprakash et al , 2006), sheep pox virus vaccine could not protect vaccinated Egyptian cattle against LSD where the high morbidity ratio of LSD in Egyptian cattle could be attributed to failure of sheep pox vaccine against LSD due to low injecting dose of the vaccine or this LSD outbreak virus is more virulent to overcome the weak immune response of the used vaccine Capstick et al, (1959). Use of sheep pox vaccine for control of LSD is recommended by Kitching (2003) because it gives reasonable immunity against LSD and also is cheaper. It is worthy to mention that Egyptian cattle were previously exposed to Strain-A of aphtho-virus of foot and mouth disease that was introduced to Egypt with African imported cattle for the first time as exotic disease in 2006. Morbidity rate of that strain was $100 \%$, consequently immune suppression of all infected cattle could be hypothesized.

Seasonal occurrence of LSD outbreak was recorded in summer season. Insects are playing very important role in the transmission of LSD virus that was mentioned by Mac Owen (1959) and Davies (1981). It was thought that introduction of more virulent strain of LSD virus, sheep pox vaccination failure in cattle, dense insects population (Chihota et al ,2003) and foot and mouth disease (strain-A) outbreak preceding LSD outbreak were gathering and enhancing the high morbidity (100\%) Capstick et al(1959). The severity of LSD and its complication

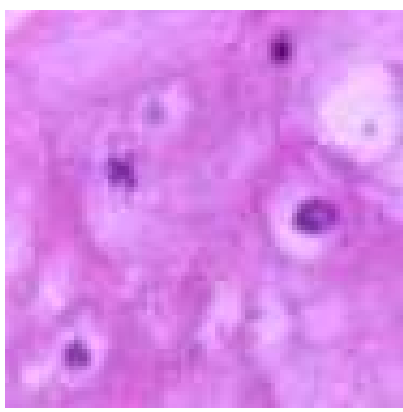

Figure-2: Epidermal layer showing intracytoplasmic inclusion body inside the stratum spinosum cell layer ( H\&E x 1000).

were much obvious in Frezian cattle than native Egyptian cattle; the much susceptibility of European cattle (Bos Taurus) to LSD than African cattle (Bos indicus). The mortality and case fatality rates among Egyptian cattle were the same $1.8 \%$, which were in the usual range of LSD (1-5\%) that was mentioned Diesel (1949) and Haig (1957). Skin nodules have congestion, hemorrhage, edema, and vasculitis with consequent necrosis and involve all layers of the epidermis, dermis, subcutaneous tissue, and often adjacent musculature. Lymph nodes draining affected areas were enlarged up to 10 times normal size with extensive lymphoid proliferation, edema, congestion, and hemorrhage. These findings coincided by Burdin (1959), Haig (1957), Prozesky and Barnard (1982), and Weiss (1968).

As shown in table (2-A), the complications of LSD were several and involving corneal opacity (Keratitis), recumbency, mastitis, cellulitis and phligmone, myiasis, abortion, dysentry, lameness, pneumonia. These complications resulted from damage of skin or mucous membranes that were followed by secondary bacterial invasion in addition to stress induced immunosuppression, anorexia, persistent fever and severe deblitation. All of that facilitate bacterial invasion of infected animal tissues to cause mastitis, corneal opacity, phelgmone, dysentry and pneumonia. Myiasis was resulted from flies attack which deposit their eggs in eroded or ulcerated skin areas, later on these eggs hatched producing very active larvae which fed on tissue exudate and caused myiasis. Recumbency resulted as LSD is deblitating disease caused cachexia and weakness and needed long time for recovery. Abortion was thought to be as result of high persistent fever not due to LSD virus attacking fetal membranes or tissues as indicated by absence of specific LSD lesions in newly borns and aborted foeti 
as well as the percentage of abortion was very low $(0.4 \%)$. Lamness was also observed due to presence of intradermal or intra-muscular LSD nodules or swellings beside joints and also due to phelgmone or cellulitis. Dysentry, diarrhea tinged with blood was observed in calves due to presence of LSD nodules in intestinal mucosa that detached and invaded by bacteria leading to haemorrhagic enteritis. Pneumonia was also resulted from bacterial inavsion of eroded areas in bronchial and tracheal mucosa. These findings agreed with that reported by Davies (1991).

As presented in table (2-B), urticaria (due to insect biting) was observed among cattle which confusing farmers with LSD (Pseudo-urticaria), both are of seasonal incidence which is summer months and developing skin lumps or swellings that was described by Shimshony (1989). Differentiation of both were depending on spontaneous recovery of urticaria within few hours and rapid response to therapy by calcium (Cal-D-Mag) and anti-histaminic injections that did not cure LSD in addition to long duration of fever and delayed recovery of LSD up to 4 months, we can reach the correct final diagnosis.

It is very important to know that prevention of LSD disease is more beneficial than its treatment to avoid high economical losses due to hide damage, loss of milk due to mastitis and loss of animal products due to deaths, abortion, fever and myiasis. So from our point of view, evaluating sheep pox vaccine as LSD vaccine to use the immunogenic and protective dose in cattle, stopping importation of african cattle from endemic areas and eradicating insects will prevent reoccurrence of that disastrous outbreak of LSD in Egypt.

\section{Acknowledgement}

We are appreciating the facilities provided to us by Department of Medicine and Infectious Diseases and Department of Pathology, Faculty of Veterinary Medicine, Cairo University, Egypt.

\section{References}

1. Ali,A.A.; Esmat,H.Attia; A. Selim and Y.M.Abdel-Hamid (1990): Clinical and pathological studies on lumpy skin disease in Egypt. Vet. Rec, 127:549-550.

2. Anonymous, D (1988): Lumpy skin disease.Vol.1.No.1, Paris: O.I.E. Disease Information.
3. Bancroft, J.D; Stevans A. and Turner D.R. (1996): Theory and practice of histological techniques. $4^{\text {th }}$ Ed. Churchill Livinigstone, Edinburgh, London, Melbourne, New York.

4. Bhanuprakash, V.; Indrani, B.K.; Hosamani, M. and Singh, R.K. (2006): The current status of sheep pox disease. Comp. Immunol. Microbiol. Infect. Dis.; 29(1):27-60.

5. Burdin, M.L. (1959): The use of histopathological examinations of skin material for the diagnosis of lumpy skin disease in Kenya. Bul. Epiz. Dis. Afr., 7:27-36.

6. Capstick,P.B., Prydie,J., Coackley,W., and Burdin,M.L. (1959): Protection of cattle against the "Neetlhing" type virus of lumpy skin disease. Vet. Rec., $71: 422$.

7. Chihota, C.M.; Rennie, L.F.; Kitching, R.P. and Mellor, P.S (2003): Attempted mechanical transmission of lumpy skin disease virus by biting insects. Med. Vet. Entomol.;17(3): 294-300.

8. Davies, F.G. (1981): Lumpy skin disease. In Virus diseases of food animals. E.P.J. Gibbs, ed. New York: Academic Press, pp. 751-764.

9. Davies, F.G. (1991): Lumpy skin disease, an African capripox virus disease of cattle. Br. Vet. J., 147:489-502.

10. Diesel , A.M.(1949): The Epizootiology of Lumpy Skin Disease in South Africa. In Proceedings of the 14th International Veterinary Congress, London, U.K., pp.492500.

11. Haig, D.A. (1957): Lumpy skin disease. Bull. Epiz. Dis. Afr., 5:421430.

12. House, J.A. (1990): Lumpy Skin Disease. In Proceedings of the 93rd Annual Meeting of the United States Animal Health Association, Las Vegas, Nevada, 1989. pp.305-314.

13. Kitching, R.P.(2003): Vaccines for lumpy skin disease, sheep pox and goat pox.Dev Biol (Basel).; 114:161-7.

14. Mac Owen, K.D.S. (1959): Observation on the epizootiology of lumpy skin disease during the first year of its occurrence in Kenya. Bull. Epiz. Dis. Afr., 7:7-20.

15. Morris, J.P.A. (1930): Pseudo-urticaria. Northern Rhodesia. Depart of Animal Health, Annual Report, p. 12.

16. Prozesky, L., and Barnard, B.J.H. (1982): A study of the pathology of lumpy skin disease in cattle. Onderstepoort J. Vet. Res., 49: 167-175.

17. Radostits, O.M.; Blood, D.C. and Gay, C.C.(1995): Veterinary Medicine, eighth edition, $2^{\text {nd }}$ printing, Bailliere Tindall, London,England.

18. Salem, A S. (1989): Lumpy Skin Disease in Egypt. In O.I.E. Dis. Infor.. Vol 2. No.2.

19. Shimshony, A. (1989): Proceedings of the 93rd Annual Meeting of the United States Animal Health Association. p 334.

20. Tuppurainen, E.S.; Venter, E.H. and Coetzer, J.A. (2005):The detection of lumpy skin disease virus in samples of experimentally infected cattle using different diagnostic techniques. Onderstepoort J. Vet. Res. ; 72(2):153-64.

21. Wayne Martin, S.et.al. (1987): Vet. Epidemiology, principles and methods. Lowa State University Press/Ames.

22. Weiss, W.E. (1968): Lumpy Skin disease. In Emerging Diseases of Animals. FAO Agricultural Studies Bulletin No. 61,pp. 179-201. 